\title{
ЗАЛОЗНОВА Ю.С.
}

чл.-кор. НАН Украӥни, д-р екон. наук, с.н.с.

заст. директора з наукової роботи

Інститут економіки промисловості НАН Украйни

вул. Желябова, 2, м. Київ, 03057

e-mail: zaloznova.iep@gmail.com

ORCID:https://orcid.org/0000-0003-3106-1490

\section{ТРУШКІНА Н.В.}

канд. екон. наук

старший науковий співробітник

Інститут економіки промисловості НАН Украӥни

вул. Желябова, 2, м. Київ, 03057

e-mail:trushkina@nas.gov.ua

ORCID https://orcid.org/0000-0002-6741-7738

\section{НАУКОВО-МЕТОДИЧНЕ ЗАБЕЗПЕЧЕННЯ ВДОСКОНАЛЕННЯ СИСТЕМИ УПРАВЛІННЯ ЛОГІСТИЧНОЮ ДІЯЛЬНІСТЮ ПІДПРИЕМСТВА}

Актуальність. На даний час актуалізуються проблеми вдосконалення управління логістичною діяльністю підприємств. Логістична складова стає стратегічно важливим чинником, щчо відображається на фінансових результатах підприємства. Логістична діяльність є основним иентром оптимізації витрат $i$, як наслідок, важелем підвищення рівня прибутковості, оскільки на ланцюг поставок припадає значна частка витрат підприємства. Отже, у сучасних умовах господарювання одним із важливіших резервів скорочення витрат $i$ підвищення ефективності функціонування вітчизняних підприємств є формування системи управління логістичною діяльністю з використанням системного підходу.

Мета та завдання. Метою статті є розробка науково-методичного забезпечення вдосконалення системи управління логістичною діяльністю підприємства.

Результати. Уточнено зміст і визначено основні елементи терміна «система управління логістичною діяльністю підприємства». Запропоновано структурну й структурно-функиіональні схеми формування системи управління логістичною діяльністю підприємства. Розроблено комплекс пропозицій щзодо вдосконалення системи управління логістичною діяльністю підприємств, до яких віднесено: управління матеріально-технічним постачанням, управління запасами, управління процесами обслуговування споживачів, управління транспортними потоками, управління збутовою діяльністю, управління ризиками логістичної діяльності, удосконалення иіноутворення, інформаційне забезпечення організації процесів логістичної діяльності на основі використання сучасних цицррових технологій і логістичних концепцій.

Висновки. Обтрунтовано, щуо впровадження пропозицій з удосконалення системи управління логістичною діяльністю підприємств сприяє економії витрат на організацію процесів матеріально-технічного забезпечення, формування запасів, транспортування та збуту продукиії.

Ключові слова: підприємство, управління логістичною діяльністю, система, принципи, методи, функціі управління, інструменти, механізм.

\section{ZALOZNOVA YU.}

Corresponding Member of the NAS of Ukraine

Doctor of Economic Sciences, Senior Research Fellow

Deputy Director for Research

Institute of Industrial Economics of NAS of Ukraine

2 Gelabov Str., Kyiv, Ukraine, 03057

ORCID 0000-0003-3106-1490

zaloznova.iep@gmail.com 
TRUSHKINA N.

Candidate of Economic Sciences

Senior Research Fellow

Institute of Industrial Economics of NAS of Ukraine

2 Gelabov Str., Kyiv, Ukraine, 03057

ORCID 0000-0002-6741-7738

trushkina@nas.gov.ua

\section{SCIENTIFIC AND METHODOLOGICAL SUPPORT OF IMPROVEMENT OF THE MANAGEMENT SYSTEM OF LOGISTIC ACTIVITIES OF THE ENTERPRISE}

Topicality. The issues of improving the management of logistics activities of enterprises are currently actualized. The logistics component is becoming strategically the most important factor that appear in the financial results of the enterprises. Logistics activity is the main centre of cost optimization and, as a consequence, the lever to raise the level of profitability, as the supply chain accounts for a substantial part of the cost of the enterprise. Thus, in modern conditions of managing one of the most important reserves of cost reduction and increase of efficiency of functioning of domestic enterprises is formation of system of management of logistic activities using a systematic approach.

Aim and tasks. The aim of this study is to develop scientific and methodological support of improving the management system of logistic activities of the company.

Research results. The concept and definition of the main elements of the term «management system of logistic activities of an enterprise» have been clarified. The structural and structural-functional schemes of formation of management system of logistic activities of the enterprise have been proposed.

To improve the management system of logistic activities of the enterprise a set of proposals has been developed on: the management of material and technical supply, the inventory management, traffic management, management of customer service processes, sales activity management, risk management of logistics activities in the risk management system of enterprises, improvement of pricing, information support of the organization of processes of logistic activity on the basis of use of modern digital technologies.

Conclusions. It is proved that the implementation of proposals for the formation of the management system of logistic activities promotes cost savings for the organization of the processes of material and technical supply, reserves, transportation and sales.

Key words: the enterprise, the management of logistics activities, system, principles, methods, management functions, tools, mechanism.

Problem statement and its connection with important scientific and practical tasks. The issues of improving the management of logistics activities of enterprises are currently actualized. The logistics component is becoming strategically the most important factor that appear in the financial results of the enterprises. Logistics activity is the main centre of cost optimization and, as a consequence, the lever to raise the level of profitability, as the supply chain accounts for a substantial part of the cost of the enterprise.

In Ukraine for the transportation and storage of products, the subjects of economic activity spend approximately $15 \%$ of GDP. In the EU countries and the USA logistics costs account for 12-16\% of GDP, in China 26\%, Japan - 6\%. Ukrainian companies annually invest about \$ 10 billion USD in the logistics. 70\% of the logistics costs are transportation costs, $25 \%$ are storage and $5 \%$ for the management of logistics flows [1, p. 29].

Thus, in modern conditions of managing one of the most important reserves of cost reduction and increase of efficiency of functioning of domestic enterprises is formation of system of management of logistic activities using a systematic approach.

Analysis of recent publications on the problem. A significant number of scientific works devoted to the conceptual framework, scientific and methodological approaches and practical recommendations to improve the efficiency of management of logistic activities of enterprises of various industries.

As the analysis of international and domestic scientific sources on logistics, shows the scientists paid much attention to the justification and development:

logistic model of distribution [2, p. 80; 3, p. 92];

proposals for improvement of supply chain management [4, p. 133; 5];

methodological approaches to determine the optimum volume of the delivery batch [6];

measures to improve the level of service and customer service $[7$, p. $1 ; 8 ; 9 ; 10 ; 11$, p. 244; 12, p. 55; $13]$ 
methodical approach to calculation of indicators of efficiency and productivity of customer service [14, p. 17];

concepts, optimization models and supply chain management strategies $[15$, p. $77 ; 16 ; 17 ; 18 ; 19 ; 20]$;

scientific and methodological bases of risk management of enterprises. practical tools to determine the logistic risk under conditions of uncertainty and the use of risk management in the management of logistic systems of enterprises in order to optimize the process of rational decision-making [21;22, p. 233; 23; 24];

tools and methods of accounting of warehouse operations using automated and information and communication technologies [25].

Allocation of previously unsolved parts of the general problem.However, despite such close attention to the identified problem on the part of scientists, it remains relevant to conduct research in the line of improving the management of logistic activities of enterprises, which must meet modern requirements of management in the context of globalization and European integration.

Formulation of research objectives (problem statement). The purpose of the article is to develop scientific and methodological support of improving the management system of logistic activities of the company.

An outline of the main results and their justification. As a result of scientific researches it is revealed that as management system of logistic activities of enterprise (MSLA) we should understand the interrelated set of objects and subjects of management through the implementation of the full range of management functions and processes of logistics activities in a single complex on the basis of use of mechanisms of information and organizational support.

The management system of logistic activities of an enterprise is a system that includes several components (processing and implementation of orders, transportation, warehousing, inventory management, customer service), performs the relevant functions and has developed relationships with the external environment, i.e. market, (intermediaries, consumers and other participants).

This is a relatively stable set of structural units (functional departments of the enterprise and participants of sales networks) interconnected and united by a common processes to control logistics activities to implement the strategic objectives of the enterprise.

The characteristic properties of MSLA of enterprises include: complexity, structure, hierarchy, emergence, flexibility, dynamism, focus on integral efficiency, synergies (synergetic effect).

The purpose of the functioning of MSLA is supported by the implementation of interrelated subsystems, functions and tasks of process to control logistics activities. This will help to reduce the cost of organizing the processes of material and technical supply, reserves, transportation and sales of finished products (Fig. 1).

Formation of management system of logistic activities of an enterprise should be based on the mechanism. As the analysis of scientific literature shows, the mechanism is considered as:

the set of processes, techniques, methods, approaches, implementation of certain actions to achieve the goal;

the sequence of stages and the set of ways;

the sequence of stages and the set of methods;

the set of events and the sequence of their use;

the way of organizing and managing the production with its inherent forms, methods and means;

the sequence of processes, phases, procedures and instruments.

The components of the mechanism may typically include tools and resources; objects and resources; methods, levers and tools; a set of forms and methods; means.

Since the activities of economic entities depends on a number of economic and financial factors (such as refusal of consumers from payments for products sold, change in contractual relationship among partners; limitation of financial resources; volatility of demand), it is reasonable to use a set of tools to be applied in the regulation of the conditions of the organization of logistic activities.

Such tools include: the price as an investment resource in the development of enterprises; contracts for the supply, which takes into account prepayment or deferred payment for goods shipped (for large consumers) and wholly in advance (for medium and small wholesale consumers); penalties in case of untimely refusal of consumers from the supply of products; forecasting as a tool for planning of logistic activities. 


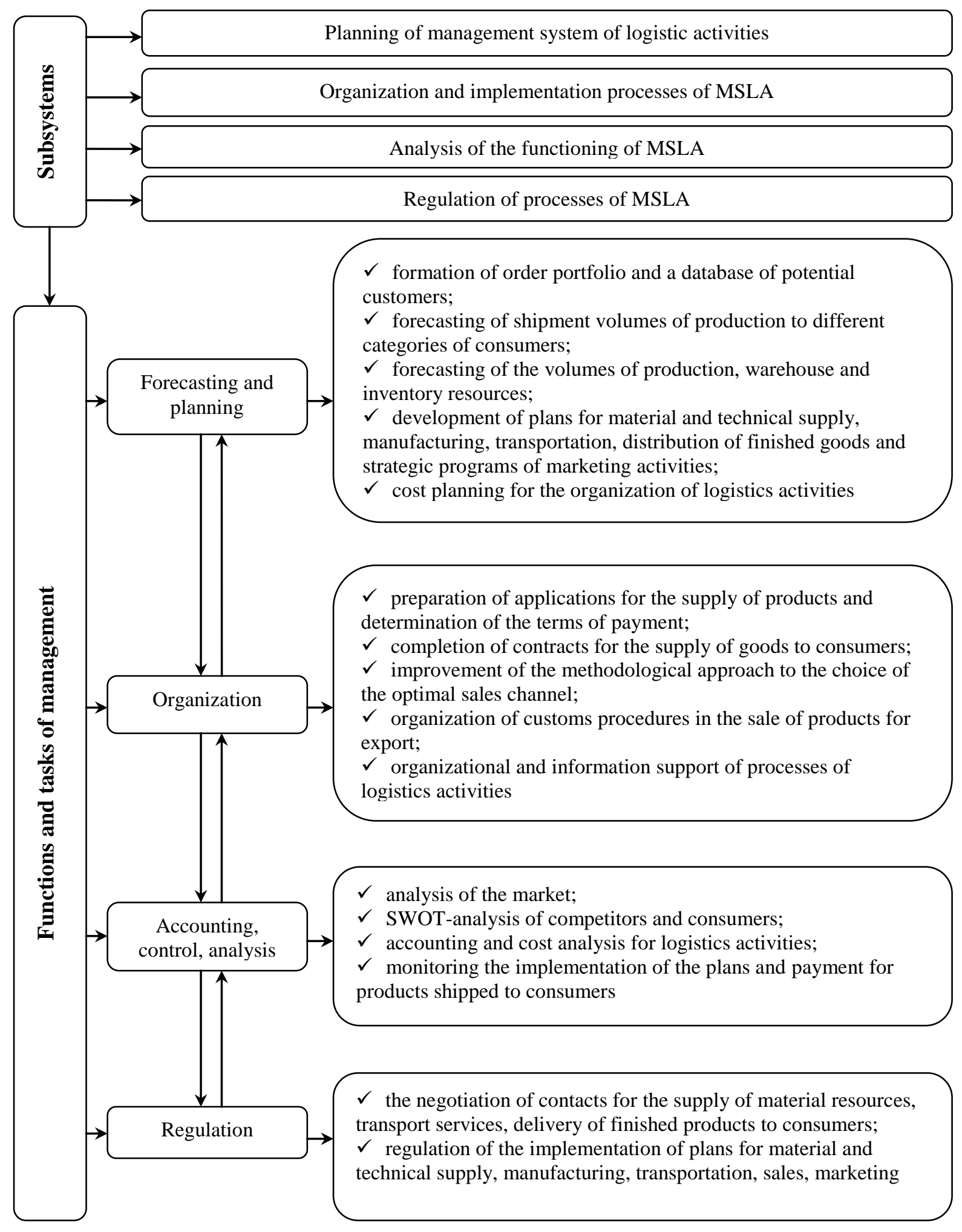

Fig. 1 Structural and functional scheme of formation of management system of logistic activities of the enterprise (author's development) 
Logistic activities is a kind of commercial activity, the implementation of which requires the realization of consequent logistics processes in a single unit, which allows to minimize the costs and losses of the enterprise taking into account influence of various risks

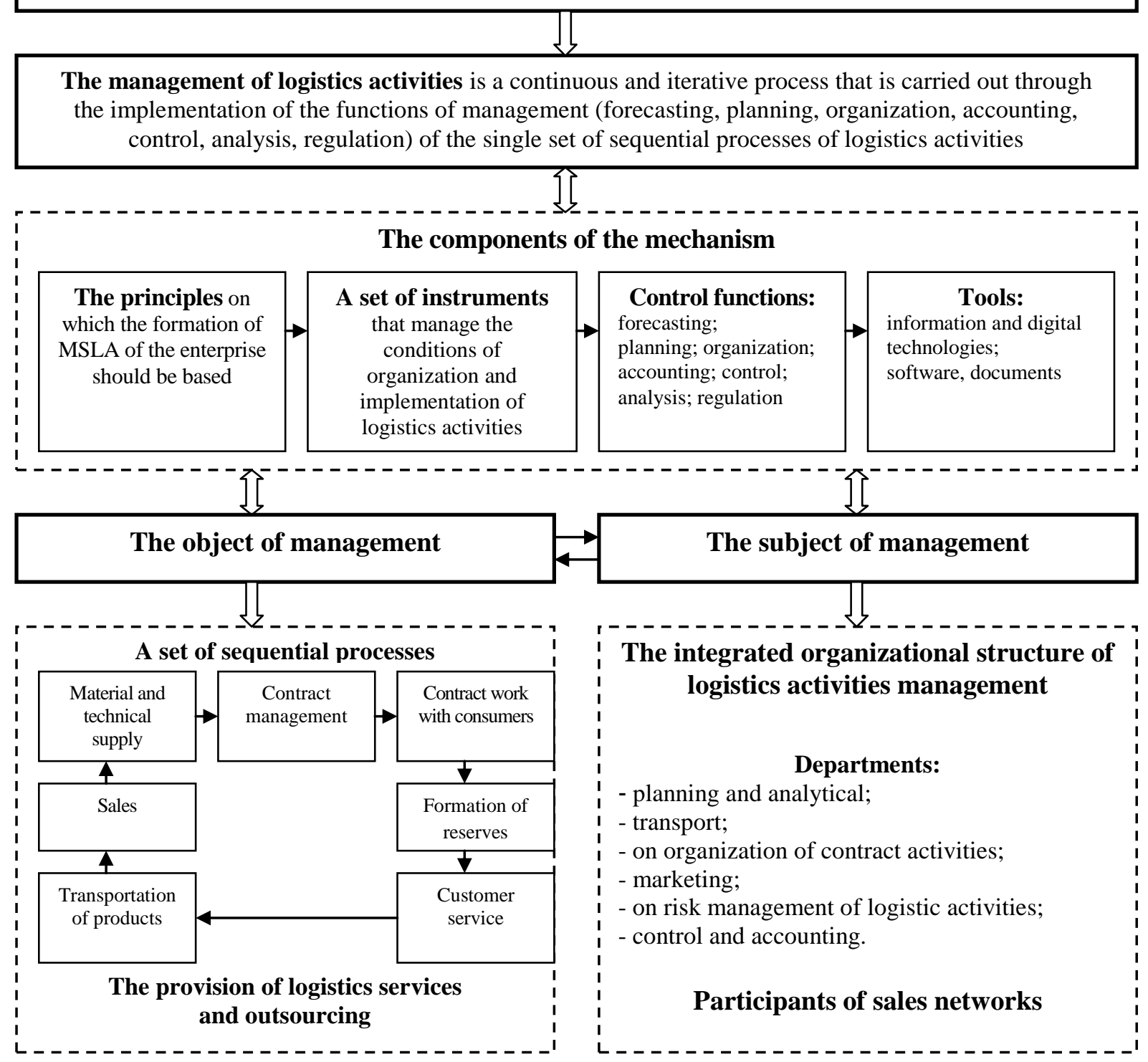

Fig. 2 The main elements of the management system of logistics activities of the enterprise (author's development)

For effective management of logistics activities of enterprises it is necessary to apply management techniques (organizational, economic, socio-psychological) and to introduce modern information systems, digital technologies and logistic concepts.

Thus, the mechanism on which the formation of MSLA of the enterprise should be based, is considered as a set of principles, tools, functions, methods, and means aimed at reducing the level of expenses for the organization of processes of logistics activities and different logistics services (transport, storage, marketing) (Fig. 2).

The mechanism is an interlinked set of economic relations, principles, methods and forms of organization of logistic processes of the enterprise

The formation of management system of logistic activities of an enterprise is understood as set of interrelated organizational, technical, economic and social measures to improve the management of logistics activities aimed at continuous improvement of the efficiency of the enterprise by reducing the level of costs, regulated by normative documents (Fig. 3). 


\section{General enterprise management system}

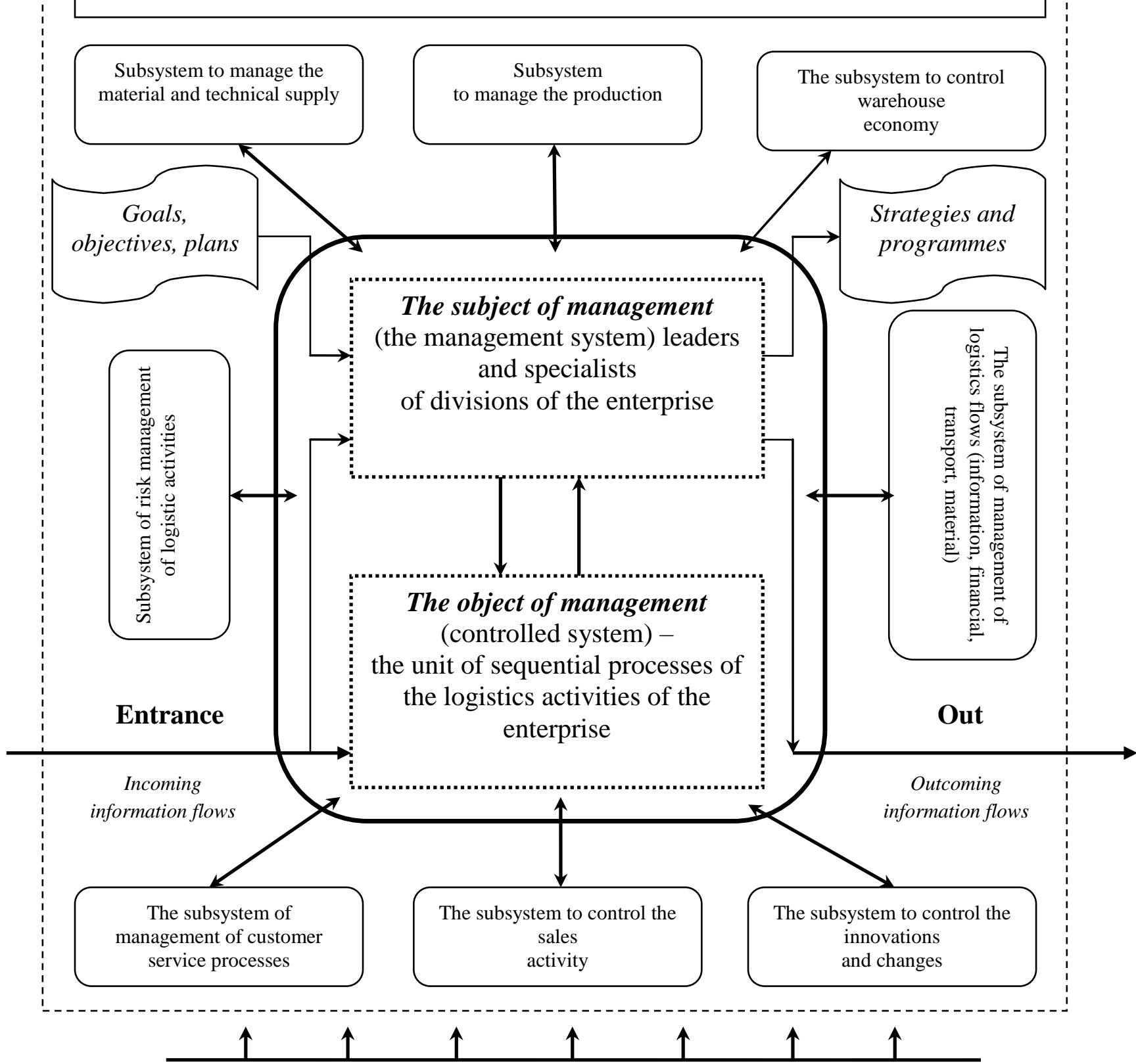

Influence of the external

Fig. 3 Structural scheme of formation of management system of logistic activities of the enterprise (author's development)

Formation of management system of logistic activities of the enterprise should be based on qualitatively new principles of functioning:

using a systematic approach to the organization of logistics activities in a single complex, the essence of which consists in the implementation of a set of interrelated, sequential processes (the study of the needs and demand of the customers, material and technical supply, transportation and warehousing of material resources, production of goods, the formation of industrial, warehouse and inventory, customer service, transportation and marketing of products) and various logistics services; 
implementation of the full range of management functions (forecasting, planning, organization, accounting, control, analysis and regulation) y the set of consistently implemented processes of logistic activities;

differentiation of consumers on a large, medium and small wholesale, based on the volumes of annual demand;

partnership relations of participants in value chains should be a voluntary cooperation, synergies of integration efforts, goals and resources of the partners, on the basis of interdependence in terms of responsibility, distribution of powers and risks of logistics activities;

the implementation of processes of the logistics activities should be based on the introduction of modern information, communication and digital technologies with use of special software of automated control systems, logistics concepts, economic and mathematical methods.

To improve the management system of logistic activities of the enterprise a set of proposals has been developed on:

the management of material and technical supply (calculation of the optimum volume of batch supply of material resources, optimization of procurement strategy of the enterprise, improving the management of the procurement process by multi-criteria evaluation of the choice of the optimum supplier of material resources);

the inventory management (analysis of inventory volumes in the warehouse, forecasting of the inventory volumes, formation of optimum inventory management strategy, development of inventory management system at enterprise, optimization of volume of production, warehouse and commodity inventory);

Table 1

\section{Systematization of the components of the effect from the formation of management system of logistic activities of the enterprise according to different scientific approaches}

\begin{tabular}{|l|l|}
\hline \multicolumn{1}{|c|}{ The components of the effect } & \multicolumn{1}{c|}{ The content of the components of the effect } \\
\hline $\begin{array}{l}\text { The formation of organizational } \\
\text { management }\end{array}$ & $\begin{array}{l}\text { reducing the cost of logistic activities by 15.3\%; } \\
\text { decrease in volume of stocks by 28\%, the processing time of customer orders - } \\
\text { by } 25.6 \% \text {; the increase in timely delivery of products to 98.9\%; } \\
\text { increase of staff productivity by 29\%. }\end{array}$ \\
\hline $\begin{array}{l}\text { Improving the system of planning, } \\
\text { accounting and analysis } \\
\text { of logistics activities }\end{array}$ & $\begin{array}{l}\text { operational planning allows to optimize the use of raw materials by 30\%; } \\
\text { reduction of expenses for purchase of material resources; } \\
\text { reducing the cost and processing time of the order by 20-40\%; } \\
\text { reducing of planning time to 95\%. }\end{array}$ \\
\hline $\begin{array}{l}\text { Optimization of production and } \\
\text { inventory resources and their } \\
\text { management costs }\end{array}$ & $\begin{array}{l}\text { reduction of inventories by 20-40\%; } \\
\text { reduction of stocks of finished goods in warehouses by 10-12\%; } \\
\text { reduction of costs for storage of stocks up to 80\%. }\end{array}$ \\
\hline Savings on transportation costs & $\begin{array}{l}\text { the introduction of the system of optimization of transport operations allows to } \\
\text { reduce transport costs by 20-40\%. }\end{array}$ \\
\hline Cost savings on sales activity & $\begin{array}{l}\text { reduction of costs of delivering products to customers by 20\%; } \\
\text { reduction of violations of the terms of supply by 30-35\%; } \\
\text { the increase in the level of service by 15-26\%; } \\
\text { reduction of terms of delivery of finished goods by 25-45\%. }\end{array}$ \\
\hline $\begin{array}{l}\text { Information support of logistics } \\
\text { business processes organization }\end{array}$ & $\begin{array}{l}\text { reduction of administrative costs for sales and marketing; } \\
\text { improving the quality of workflow; } \\
\text { reduction of cost of sales, marketing and customer support by 10-15\%; } \\
\text { improving the accuracy of forecasting sales up to 80\%; } \\
\text { reduction of time for execution of current operations by 25-30\%; } \\
\text { growth of profitability of sales by 15-20\%. }\end{array}$ \\
\hline
\end{tabular}

Made according to: [26-30].

traffic management (implementation of cargo management information systems, application of automated processing of documents on completion of transportation of goods, development of proposals to optimize the load of transport, use of Internet technology for automation of transport processes);

management of customer service processes (analysis of the volume of shipment of products, forecasting of volumes of shipment of products to consumers, formation of a system of contractual relationships with consumers, improvement of customer-oriented approach to the service of different 
categories of consumers in the context of the concept of relationship marketing, development of proposals to improve the level of logistic services);

sales activity management (rationale for the use of a network approach to the organization of sales activities of enterprises, mechanism of implementation of public-private partnership in the management of sales activities of enterprises on the basis of the legal form of syndicate, methodical approach to the selection of the optimum sales channel of finished product, identification of priority areas of e-commerce development as an effective tool for product promotion in the market);

improvement of pricing (pricing of material resources and products ready for shipment);

risk management of logistics activities in the risk management system of enterprises with the use of a range of methods and tools that enable continuous monitoring and system analysis to predict the occurrence of risk situations in a timely manner and to implement measures to address them;

information support of the organization of processes of logistic activity on the basis of use of modern digital technologies.

Implementation of the above proposals will contribute to achieving the effect due to the processes of logistics activities in a single complex and reduce costs for their organization. This is confirmed by research of scientists, which determined the components of the effect in the result of formation of system of management of logistics activities (see table).

Conclusions and perspectives of further research. The study developed a scientific and methodical provision ensuring improvement of the management system of logistic activities of the enterprise, which is the clarification of the term «management system of logistic activities of the enterprise» and the definition of components of the mechanism on the basis of which the formation of MSLA should be based.

Implementation of proposals for the formation of management system of logistic activities of the enterprise helps save the cost of logistic activities as a result of:

reduction of the cost of material and technical supply, storage, transportation and sales activities on the basis of greater coherence of actions between members of sales networks;

reduction of time on customer service;

improving the quality of service and level of service of various categories of consumers.

The prospect of further scientific research is the development of organizational and economic mechanism in the management system of logistic activities of the enterprise.

\section{ЛІТЕРАТУРА}

1. Кислий В. Розвиток транспортно-логістичних кластерів в Україні / В. Кислий, Т. Жарик // Економіка України. - 2010. - № 12. - С. 28-37.

2. Boom A. Fachkonzeptuelle Modellierung eines Kooperations-informatiossystems / Andre van den Boom // Unter Berucksichtigung von Informationssystem-Konzeptualisierungen und institutionenokonomischen Ansatzen. - Aachen: Shaker Verlag, Gmbh, 2007. - 277 s.

3. Маркетингова політика розподілу / С.В. Крикавський, Н.С. Косар, А. Чубала. - 2-е вид. Львів: Видавництво Львівської політехніки, 2012. - 260 с.

4. Huemer L. Supply Management: Value creation, coordination and positioning in supply relationships / Lars Huemer // Long Range Planning. - 2006. - Vol. 39. - No. 2. - P. 133-153. doi: 10.1016/j.lrp.2006.04.005.

5. Баррат К. Покупки для бизнеса. Что такое снабжение и управление поставками / К. Баррат, М. Уайтхед. - Москва: Олимп-Бизнес, 2008. - 276 с.

6. Шрайбфедер Дж. Эффективное управление запасами / Дж. Шрайбфедер. - Москва: Альпина Бизнес Букс, 2006. - 304 с.

7. Gunasekaran A. Editorial: New service and manufacturing environments: challenges for operations management researchers and practitioners / Angappa Gunasekaran // International Journal of Services and Operations Management. - 2005. - Vol. 1. - No. 1. - P. 1-6. doi: 10.1504/IJSOM.2005.006313.

8. Payne A. Handbook of CRM. Achieving Excellence in Customer Management / A. Payne. Oxford: Butterworth-Heinemann is an imprint of Elsevier Linacre House, 2005. - $460 \mathrm{p}$.

9. Kotler P. Marketing Management / P. Kotler, K.L. Keller. - 14th edition. - Upper Saddle River, New Jersey: Prentice Hall, 2014. - 720 p. 
10. Ламбен Ж.-Ж. Менеджмент, ориентированный на рынок / Ж.-Ж. Ламбен. - СПб.: Питер, 2007. $-800 \mathrm{c}$.

11. Souitaris V. Tailoring online retail strategies to increase customer satisfaction and loyalty / V. Souitaris, G. Balabanis // Long Range Planning. - 2007. - Vol. 40. - No. 2. - P. 244-261. doi: 10.1016/j.lrp.2006.11.006.

12. Wallenburg C. Der differenzierte Einfluss unterschiedlicher Performance-Level auf die Kundenbindung bei Logistikdienstleistungen / C. Wallenburg // Zeitschrift für Betriebswirtschaft. Special Issue. Forschungsperspektiven der betriebswirtschaftlichen Logistik. - 2008. - No 4. - S. 55-82.

13. Партнерські відносини на ринку В2В та В2С: монографія / С. Крикавський, 3. Люльчак, Я. Циран, І. Петецький. - Львів: Вид-во Львівської політехніки, 2015. - 232 с.

14. Oke S.A. An approach to measuring the quality of maintenance performance / S.A. Oke, M.K.O. Ayomoh, I.O. Oyedokun // IMA Journal of Management Mathematics. - 2007. - Vol. 18. - No. 1. P. 17-32. doi: 10.1093/imaman/dpi045.

15. Beresford A.K.C. Improving supply chain performance through quality management in a global distribution environment / A.K.C. Beresford, S.J. Pettit, W. Whittaker // International Journal of Services and Operations Management. - 2005. - Vol. 1. - No. 1. - P. 75-89. doi: 10.1504/IJSOM.2005.006319.

16. Харрисон А. Управление логистикой. Разработка стратегий логистических операций / А. Харрисон, Р. Хаук. - Москва: Баланс Бизнес Букс, 2007. - 368 с.

17. Сандер Г. Логистика. Искусство управления цепочками поставок / Г. Сандер, Д. Шехтер. Москва: Претекст, 2008. - 252 с.

18. Blaik P. Logistyka. Koncepcja zintegrowanego zarzadzania / P. Blaik. - Warszawa: Polskie Wydawnictwo Ekonomiczne, 2010. - $480 \mathrm{~s}$.

19. Мэрфи Пол Р. Современная логистика / Пол Р. Мэрфи, Дональд Ф. Вуд. - 8-е изд. Москва: ООО «И.Д. Вильямс», 2017. - 720 с.

20. Бауэрсокс Дональд Дж. Логистика: интегрировання цепь поставок / Дональд Дж. Бауэрсокс, Дейвид Дж. Клосс. - 2-е изд. - Москва: Олимп-Бизнес, 2017. - 640 с.

21. Damodaran A. Strategic risk taking: A framework for risk management / A. Damodaran. Pennsylvania: Pearson Prentice Hall, 2008. - 408 p.

22. Fuchs H. Risk management in logistics systems / H. Fuchs, J.W. Wohinz // Advances in Production Engineering \& Management. - 2009. - Vol. 4, No 4. - P. 233-242.

23. Andersen T. Strategic risk management practice; How to deal effectively with major corporate exposures / T. Andersen, P. Schreder. - Cambridge: Cambridge University Press, 2010. - 268 p.

24. Crouhy M. Risk management / M. Crouhy, D. Galai, R. Mark. - New York: McGraw-Hill, 2012. $390 \mathrm{p}$.

25. Фразелли Э. Мировые стандарты складской логистики / Э. Фразелли. - Москва: Альпина Паблишер, 2013. - 376 с.

26. Радикальная реструктуризация службы логистики группы компаний Geberit GmbH. Совокупная выгода и удовлетворение запросов потребителей посредством комплексной стратегии // Бюллетень Украинской логистической ассоциации. - 2012. - № 4. - С. 51-56.

27. Неруш Ю.М. Логистика / Ю.М. Неруш. - М.: ЮНИТИ-ДАНА, 2009. - 390 с.

28. Гаджинский А.М. Логистика / А.М. Гаджинский. - 20-е изд., перераб. и доп. - М.: Дашков и К, 2012. $-484 \mathrm{c}$.

29. Силенко А.Н. Оптимизация деятельности предприятия на основе концепции CRM (управление взаимоотношениями с клиентом) / А.Н. Силенко, М.В. Трубников // Экономические стратегии. - 2009. - № 2. - С. 102-109.

30. Капінус Л.В. Доцільність впровадження клієнтоцентризму на підприємстві / Л.В. Капінус // Формування ринкових відносин в Україні. - 2008. - № 4 (83). - С. 46-50.

\section{REFERENCES}

1. Kyslyi, V., Zharik, T. (2010). Rozvytok transportno-lohistychnykh klasteriv $v$ Ukraini [Development of transport and logistics clusters in Ukraine], Economy of Ukraine, vol. 12, pp. 28-37 [in Ukrainian]. 
2. Boom, A. (2007). Fachkonzeptuelle Modellierung eines Kooperations-informatiossystems, Unter Berucksichtigung von Informationssystem-Konzeptualisierungen und institutionenokonomischen Ansatzen, Shaker Verlag, Gmbh, Aachen [in German].

3. Krykavs'kyj, Ye.V., Kosar, N.S., Chubala, A. (2012). Marketynhova polityka rozpodilu [Marketing Distribution Policy], 2nd ed, Vydavnytstvo L'vivs'koi politekhniky, L'viv, Ukraine [in Ukrainian].

4. Huemer, L. (2006). Supply Management: Value creation, coordination and positioning in supply relationships, Long Range Planning, vol. 39, issue 2, pp. 133-153. DOI: 10.1016/j.lrp.2006.04.005 [in English].

5. Barrat, K., Whitehead, M. (2008). Pokupki dlja biznesa. Chto takoe snabzhenie i upravlenie postavkami [Buying for Business: Insights in Purchasing and Supply Management], Olymp-Business, Moscow [in Russia].

6. Schreibfeder, J. (2006). Jeffektivnoe upravlenie zapasami [Efficient Inventory Management], Alpina Business Books, Moscow [in Russia].

7. Gunasekaran, A. (2005). Editorial: New service and manufacturing environments: challenges for operations management researchers and practitioners, International Journal of Services and Operations Management, vol. 1, no. 1, pp. 1-6. DOI: 10.1504/IJSOM.2005.006313 [in English].

8. Payne, A. (2005). Handbook of CRM. Achieving Excellence in Customer Management, Butterworth-Heinemann is an imprint of Elsevier Linacre House, Oxford [in English].

9. Kotler, P., Keller, K.L. (2014). Marketing Management, 14th ed, Prentice Hall, Upper Saddle River, New Jersey [in English].

10. Lamben, J.-J. (2007). Menedzhment, orientirovannyj na rynok [Market-driven Management. Strategic \& Operational Marketing], Peter, St.-Petersburg [in Russia].

11. Souitaris, V., Balabanis, G. (2007). Tailoring online retail strategies to increase customer satisfaction and loyalty, Long Range Planning, vol. 40, issue 2, pp. 244-261. DOI: 10.1016/j.lrp.2006.11.006 [in English].

12. Wallenburg, C. (2008). Der differenzierte Einfluss unterschiedlicher Performance-Level auf die Kundenbindung bei Logistikdienstleistungen, Zeitschrift für Betriebswirtschaft, Special Issue. Forschungsperspektiven der betriebswirtschaftlichen Logistik, no 4, s. 55-82 [in German].

13. Krykavs'kyj, Ye., Liul'chak, Z., Tsyran, Ya., Petets'kyj, I. (2015). Partners'ki vidnosyny na rynku $V 2 V$ ta V2S [Partnership relations in B2B and B2C markets], Vydavnytstvo L'vivs'koi politekhniky, L'viv, Ukraine [in Ukrainian].

14. Oke, S.A., Ayomoh, M.K.O., Oyedokun, I.O. (2007). An approach to measuring the quality of maintenance performance, IMA Journal of Management Mathematics, vol. 18, issue 1, pp. 17-32. DOI: 10.1093/imaman/dpi045 [in English].

15. Beresford, A.K.C., Pettit, S.J., Whittaker, W. (2005). Improving supply chain performance through quality management in a global distribution environment, International Journal of Services and Operations Management, vol. 1, no. 1, pp. 75-89. DOI: 10.1504/IJSOM.2005.006319 [in English].

16. Harrison, A., Hauck, R. (2007). Upravlenie logistikoj. Razrabotka strategij logisticheskih operacij [Logistics Management and Strategy], Balance Business Books, Moscow [in Russia].

17. Sander, G., Shehter, D. (2008). Logistika. Iskusstvo upravlenija cepochkami postavok [Delivering the Goods: The Art of Managing Your Supply Chain], Pretext, Moscow [in Russia].

18. Blaik, P. (2010). Logistyka. Koncepcja zintegrowanego zarzadzania, Polskie Wydawnictwo Ekonomiczne, Warszawa [in Poland].

19. Murphy, Paul R., Wood, Donald F. (2017). Sovremennaja logistika [Contemporary Logistics], 8thed, I. D. Williams LLC, Moscow [in Russia].

20. Bowersox, Donald J., Closs, David J. (2017). Logistika: integrirovannja cep' postavok [Logistical Management: The Integrated Supply Chain Process], 2nd ed, Olymp-Business, Moscow [in Russia].

21. Damodaran, A. (2008). Strategic risk taking: A framework for risk management, Pearson Prentice Hall, Pennsylvania [in English].

22. Fuchs, H., Wohinz., J.W. (2009). Risk management in logistics systems, Advances in Production Engineering \& Management, vol. 4, no 4, pp. 233-242. URL: http://apemjournal.org/Archives/2009/APEM4-4_233-242.pdf [in English].

23. Andersen, T., Schreder, P. (2010). Strategic risk management practice; How to deal effectively with major corporate exposures, Cambridge University Press, Cambridge [in English]. 
24. Crouhy, M., Galai, D., Mark, R. (2012). Risk management, McGraw-Hill, New York [in English].

25. Frazelle, E. (2013), Mirovye standarty skladskoj logistiki [World-Class Warehousing and Material Handling], Alpina Publisher, Moscow [in Russia].

26. Radikal'naja restrukturizacija sluzhby logistiki gruppy kompanij Geberit GmbH. Sovokupnaja vygoda $i$ udovletvorenie zaprosov potrebitelej posredstvom kompleksnoj strategii [Radical restructuring of logistics of companies group Geberit $\mathrm{GmbH}$. Added value and customer satisfaction through a comprehensive strategy] (2012). Bulletin of the Ukrainian logistics Association, no. 4, pp. 51-56 [in Russia].

27. Nerush, Yu.M. (2009). Logistika [Logistics], YUNITI-DANA, Moscow [in Russia].

28. Hadzhinski, A.M. (2012). Logistika [Logistics], 20th ed, Dashkov I K, Moscow [in Russia].

29. Silenko, A.N., Trubnikov, M.V. (2009). Optimizacija dejatel'nosti predprijatija na osnove koncepcii CRM (upravlenie vzaimootnoshenijami s klientom) [Optimization of activity of the enterprise on the basis of the CRM concept (customer relationship management)]. Economic strategies, no. 2, pp. 102-109 [in Russia].

30. Kapinus, L.V. (2008). Dotsil'nist' vprovadzhennia kliientotsentryzmu na pidpryiemstvi [Expediency of implementation of client-centricity at the enterprise]. Formation of market relations in Ukraine, no 4 (83), pp. 46-50 [in Ukrainian]. 